\title{
Nilai TBA, FFA, Kadar Air Dan Sifat Sensori Keripik Kentang Berdasarkan Jenis Kemasan Dan Lama Penyimpanan
}

\author{
Value Of TBA, FFA, Water Condition And Potato Chemical Sensor Precision Based On \\ Types Of Package And Old Storage \\ Azqia Fajriyani, Wikanastri Hersoelistyorini, Nurhidajah \\ Program Studi S1 Teknologi Pangan \\ Universitas Muhammadiyah Semarang \\ E-mail : azqiafajriyani@gmail.com
}

\begin{abstract}
Potato (Solanum tuberosum L.) is one type of tubers are widely consumed by the community because it tastes good and contains high carbohydrates. Potato damage easily occurs because the water content in potatoes is high enough that is 80 percent. Based on that, it is necessary to do the processing to extend the life of the potato store. This study aims to determine the effect of packaging type and storage time to the value of TBA, FFA, Water Content and Sensory Character of Potato Chips. This study used a factorial completely randomized design consisting of 2 factors: packaging type (PP, PE, and aluminum foil) with each thickness of $0.5 \mathrm{~mm}$ and storage time ( 0 days, 7 days, 14 days, 21 days and 28 day) in room temperature. The result of statistical test showed that the type of packaging and storage time had an effect on FFA value, water content and sensory character of potato chips while the value of TBA had no significant effect. Level of potato chip TB $A$ at end of shelf in packing PP 2,412 mg malonaldebid / $\mathrm{kg}$ sample, PE 3,365 mg malonaldebid / kg and aluminum foil 2,787 mg malonaldebid / kg sample. FFA value at end of shelf life on packing PP1,173\% ALB sample, PE 1,548\% ALB sample, and Alumunium foil 1.173\% ALB sample. Water content at end of shelf life on PP 7.040\%, PE 3,933\%, and Alumunium foil 3,003\%. The result of statistical test shows that there is influence of packaging type and storage time to FF $A$ value, water content and sensory character of potato chips.
\end{abstract}

Keywords: Chips, Potatoes, Storage, and TBA

\section{PENDAHULUAN}

Keripik kentang merupakan makanan ringan (snack food) yang lebih mengutamakan karakterisik (appereance), kerenyahan (texture) dan warna dibandingkan kandungan gizinya. Menurut Adiyoga et al. (1999), keripik kentang secara umum adalah produk yang dihasilkan melalui tahapan pengupasan, pengirisan, perendaman dalam larutan dan penggorengan. Faktor-faktor yang menentukan kualitas keripik kentang yaitu warna, kenampakan, cita rasa, tekstur, kandungan minyak, kandungan air dan nilai gizi. Penelitian Wijayanti menghasilkan, parameter mutu kritis dari pendugaan umur simpan keripik pisang adalah kadar air.

Selain kadar air, kerusakan produk pangan juga disebabkan oleh ketengikan akibat terjadinya oksidasi atau hidrolisis komponen bahan pangan seperti lemak, protein dan lain-lain. Menurut Dewi et al. 
(2012), ketengikan (rancidity) merupakan kerusakan atau perubahan bau dan flavor dalam lemak atau bahan pangan berlemak. Lama pemanasan minyak dapat mengakibatkan perubahan nilai angka peroksidanya, sehingga akan mempengaruhi kualitas pada bahan yang digoreng. Disamping itu ketersediaan oksigen dalam kemasan juga akan mempengaruhi terjadinya proses ketengikan. Tingkat kerusakan tersebut dapat diketahui melalui analisis Free fatty acid (FFA) dan Tiobarbituric acid (TBA) (Herawati, 2008). Rahayu (2007) mengungkapkan, pemilihan jenis kemasan sangat penting, agar kadar air dari bahan tidak mengalami perubahan selama masa penyimpanan.

Menurut Hutasoit (2009), umur simpan merupakan salah satu masalah utama yang seringkali dijumpai pada industri dalam mengembangkan dan memasarkan produk. Ketepatan pemilihan jenis kemasan sangat berpengaruh pada daya tahan produk hingga sampai pada konsumen. Mudjisihono et al. (2001) menyatakan bahwa, jenis kemasan plastik efektif untuk menghambat perubahan kadar air selama penyimpanan. Tujuan dari penelitian ini adalah untuk mengukur lama simpan keripik kentang dengan tiga macam kemasan yaitu Polyprophylene, Polethylene dan alumunium foil.

\section{BAHAN DAN METODE}

\section{Bahan}

Bahan yang digunakan dalam pembuatan keripik kentang adalah kentang, garam, minyak goreng, dan bahan-bahan kimia yaitu HCL 4 M, Thiobarbituric acid (TBA), $\quad \mathrm{NaOH} \quad 0,1 \mathrm{~N}$, indikator $\mathrm{PP}$ (Phenolphtealin) dan alkohol. Alat yang digunakan meliputi timbangan elektronik, Spektrofotometer, deep frying, vacum seller, oven, alat distilasi, plastik Polyethylene, plastik Polypropylene dan Alumunium foil ketebalan 0,5 mm dan seperangkat alat-alat kimia.

\section{Rancangan Penelitian}

Penelitian ini menggunakan Rancangan Acak Lengkap Faktorial (RAL Faktorial), dengan 3 kali ulangan. Sebagai perlakuan jenis kemasan menggunakan plastik PP, PE dan Alumunium foil. Sedangkan untuk lama penyimpanan dibagi menjadi 5 variasi yaitu 0 hari, 7 hari, 14 hari, 
21 hari, dan 28 hari. Adapun parameter pengamatan pada penelitian ini yaitu bilangan TBA (Thiobarbituric acid), Free fetty acid (FFA), kadar air dan sifat sensori keripik kentang.

\section{Analisis Data}

Analisis data hasil uji TBA, FFA, dan kadar air yang diperoleh dianalisa deskripstif dan statistik menggunakan uji Anova faktorial dengan bantuan Software SPSS 20.0 dan jika ada pengaruh dimana $\mathrm{p}$-value $<0,05$ maka diuji lanjut dengan uji Tukey. Dan data hasil pengukuran sifat sensori yang diperoleh dianalisa deskriptif dan statistik menggunakan uji Friedman dan jika ada pengaruh dimana $\mathrm{p}$-value $<0,05$ maka diuji lanjut dengan uji Wilcoxon untuk mengetahui ada beda.

\section{Prosedur Analisis}

Parameter yang diuji meliputi : Nilai TBA metode (Apriyantono et al. 1989); Nilai FFA metode (Erna Wati Ibnu Hajar dan Sirril Mufidah, 2016); Kadar Air metode Oven (AOAC, 2005), dan Sifat Sensori metode Metode Hedonik dan Skoring (Soekarto, 2007).

\section{Prosedur Penelitian}

\section{Pembuatan Keripik Kentang (Hani, 2012}

\section{Modifikasi)}

Proses pembuatan keripik kentang diawali dengan pengupasan kulit kentang, kemudian pencucian menggunakan air mengalir, selanjutnya ditimbang sesuai dengan perlakuan. Dilanjutkan dengan pemotongan kentang dengan ketebalan 2-3 $\mathrm{mm}$ berbentuk chips setelah itu penggorengan menggunakan deep frying dengan suhu $\pm 180^{\circ} \mathrm{C}$ selama $10-15$ menit. Tahap berikutnya pendinginan dengan cara keripik kentang yang sudah jadi didiamkan pada suhu ruang selama \pm 15 menit hal ini dilakukan aga keripik kentang dimudah hancur pada saat melalui proses penirisan. Tahap terakhir adalah penirisan menggunakan Spinner selama 90 detik, kemudian keripik kentang dikemas menggunakan plastik PP, PE, dan alumunium foil.

Uji asam Thiobarbiturat (TBA) dipakai untuk menentukan adanya ketengikan 
(Winarno, 1997). Menurut Muchtadi et al.

(2011) selama penyimpanan minyak dan

lemak mengalami proses oksidasi

menghasilkan komponen seperti aldehid,

keton dan asam lemak bebas yang menyebabkan ketengikan.

Sammet et al. (2006) menyebutkan

dalam penelitiannya bahwa semakin

lama waktu penyimpanan maka bilangan TBA semakin meningkat.

Menurut Winarno (1991), peningkatan nilai TBA selama penyimpanan terjadi karena adanya kerusakan lemak yang menyebabkan timbulnya bau dan rasa tengik akibat reaksi oksidasi antara asam lemak tidak jenuh yang terdapat dalam produk pangan dengan udara

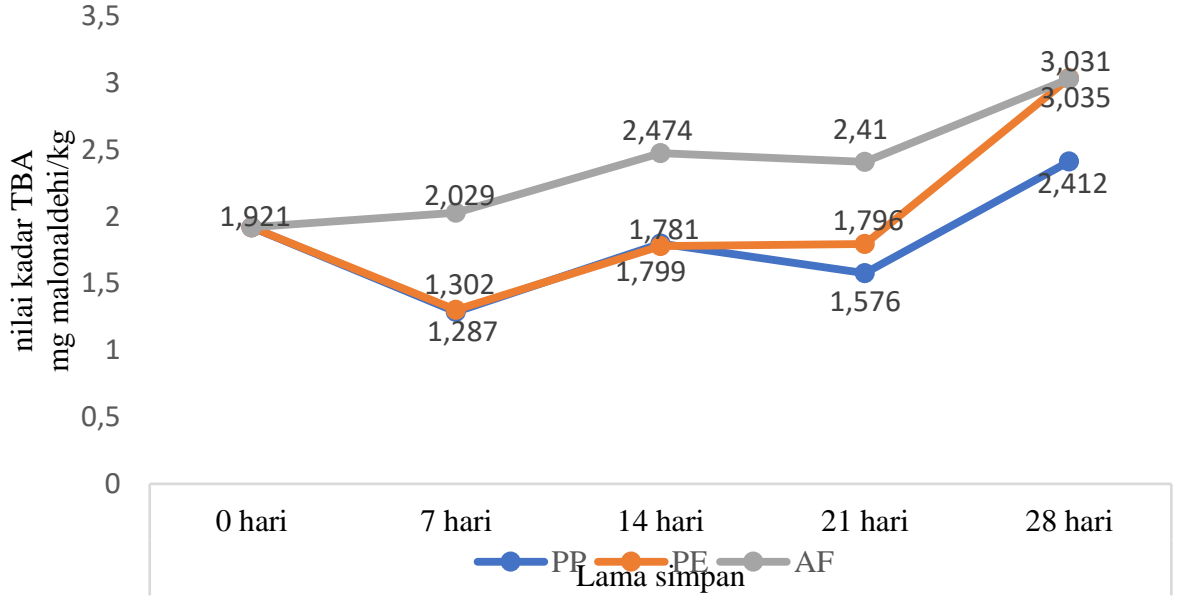

Gambar 1. Rata-rata hasil analisis nilai TBA keripik kentang berdasarkan jenis kemasan dan lama penyimpanan.

Hasil analisis menggunakan sidik ragam dua faktor menunjukkan bahwa jenis kemasan menunjukkan nilai $P=0,279>0,05$ dan lama penyimpanan menunjukkan $P=0,022<0,05$ dan dari kedua interaksi tersebut menunjukkan bahwa jenis kemasan dan lama penyimpanan memiliki $P=0,732>0,05$. Dapat disimpulkan keripik kentang dengan kedua interkasi antara penggunaan jenis kemasan dan lama penyimpanan keripik kentang tidak 
berpengaruh terhadap nilai TBA keripik

Nilai FFA

Menurut Nurhasnawati et al. (2015), asam lemak bebas terbentuk karena proses oksidasi dan hidrolisa kentang.

enzim selama pengolahan dan penyimpanan. Kandungan asam lemak bebas yang tinggi akan berpengaruh terhadap kualitas produk yang digoreng

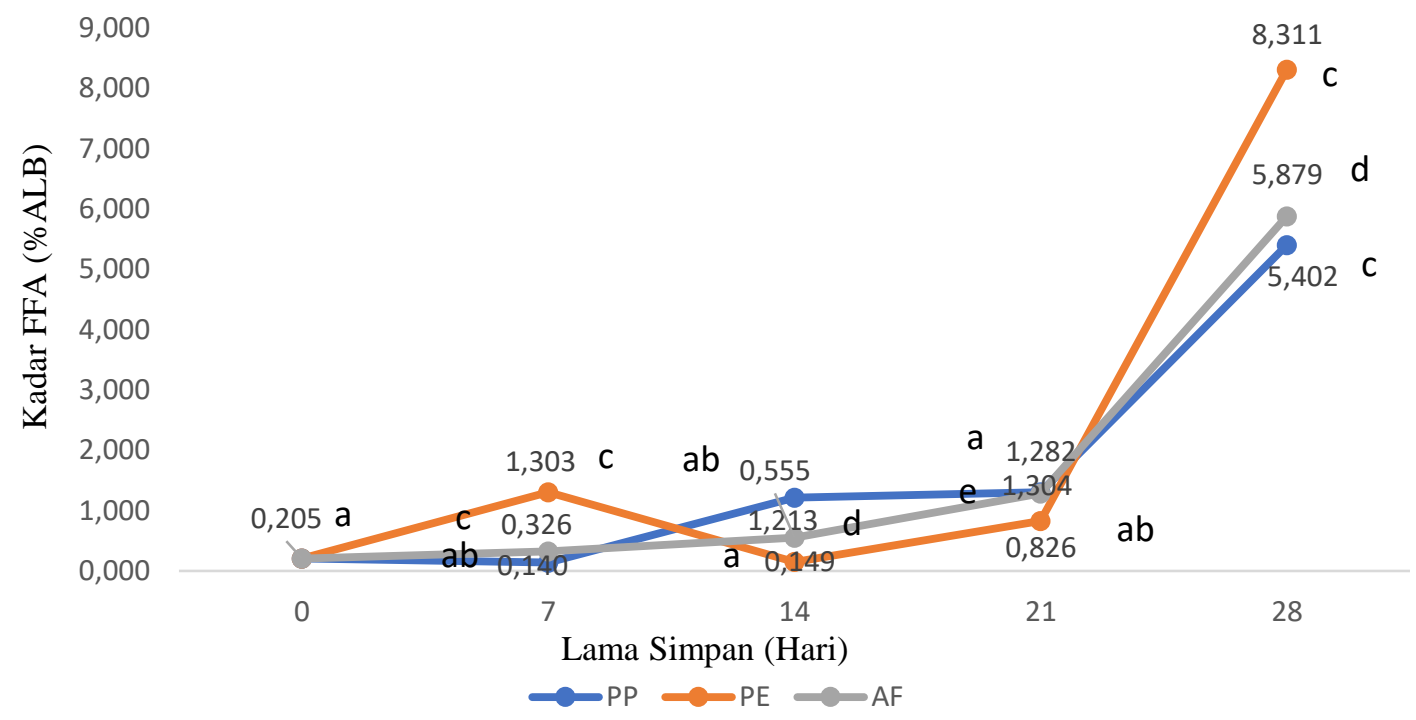

Gambar 2. Rata-rata hasil analisis nilai FFA keripik kentang berdasarkan jenis kemasan dan lama penyimpanan.

Hasil analisis menggunakan sidik ragam dua faktor menunjukkan bahwa jenis kemasan dan lama penyimpanan ada pengaruh dimana $\mathrm{P}=0,00<0,05$ terhadap nilai FFA. Semakin lama penyimpanan, maka nilai FFA semakin tinggi. Interaksi

\section{Nilai kadar air}

Kadar air dalam produk pangan merupakan faktor penting dalam penentuan antara jenis kemasan dengan lama penyimpanan menunjukkan adanya perbedaan $\mathrm{P}=0,00<0,05$ terhadap nilai $\mathrm{FFA}$. Uji lanjut Tukey menunjukkan ada perbedaan nyata antara jenis kemasan dengan lama penyimpanan keripik kentang. umur simpan. Penelitian Wijayanti (2011) menyatakan parameter mutu kritis dari 
pendugaan umur simpan keripik pisang adalah kadar air.

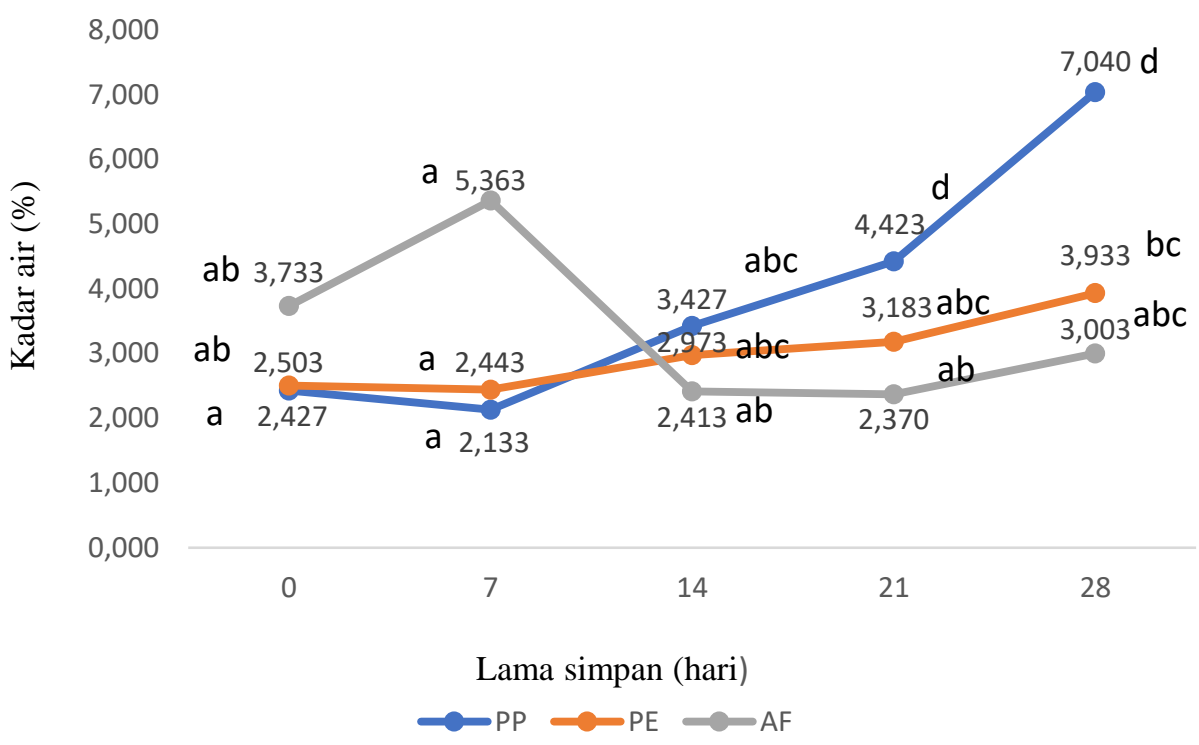

Gambar 3. Rata-rata hasil analisis nilai kadar air keripik kentang berdasarkan jenis

kemasan dan lama penyimpanan.

Hasil analisis menggunakan sidik ragam dua faktor pada keripik kentang menunjukkan ada pengaruh keripik kentang terhadap jenis kemasan dan lama penyimpanan. Dimana nilai dari interaksi antara jenis kemasan dan lama penyimpanan menunjukkan nilai $\mathrm{P}=0,015<0,05$ hal ini dapat disimpulkan bahwa jenis kemasan dan

\section{Sifat Sensori Keripik Kentang}

\section{Warna}

Warna merupakan visualisasi suatu produk yang langsung terlihat lebih dahulu dibandingkan dengan variabel lainnya. lama simpan berpengaruh terhadap mutu dan masa simpan keripik kentang. Semakin lama masa simpan maka kadar air pada keripik kentang semakin meningkat. Uji lanjut Tukey menunjukkan ada perbedaan nyata antara jenis kemasan dengan lama penyimpanan keripik kentang.

Warna secara langsung akan mempengaruhi persepsi panelis, menurut Winarno (2002), secara visual faktor warna akan tampil lebih dahulu dan seringkali menentukan nilai suatu produk. 


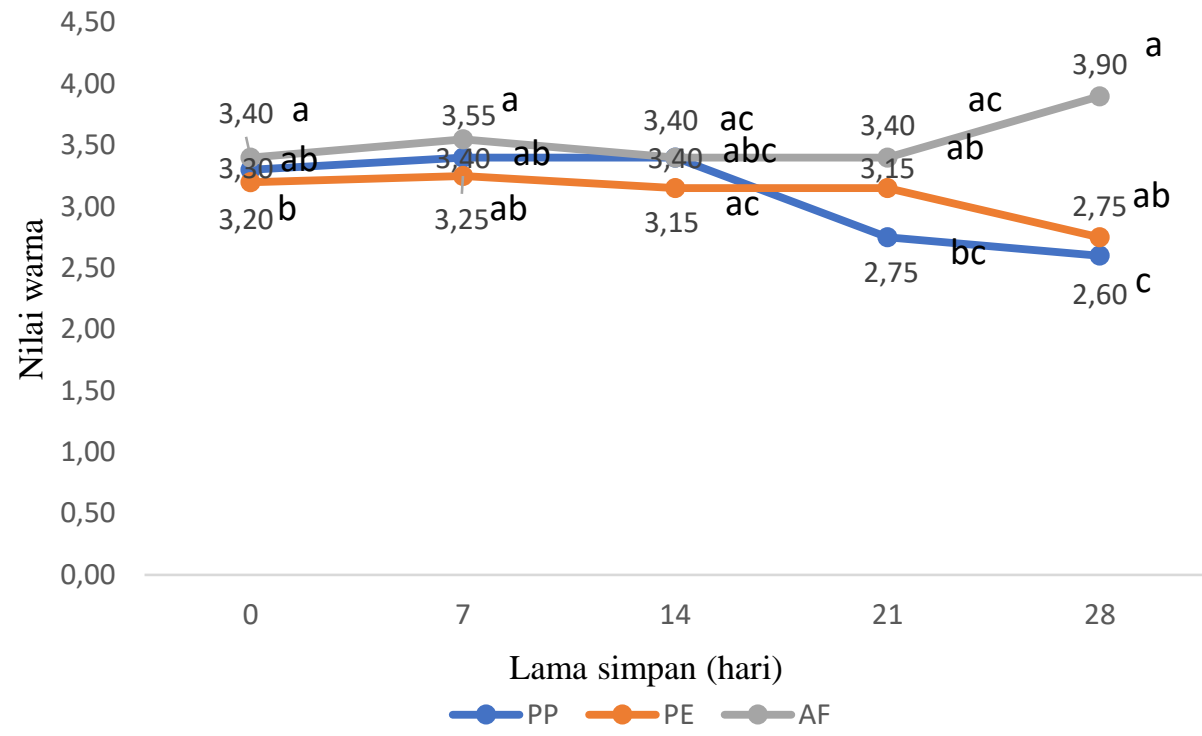

Gambar 4. Rata-rata hasil analisis nilai warna keripik kentang berdasarkan jenis kemasan dan lama penyimpanan

Uji statistik Friedman menunjukkan

nilai $P=0,00<0,05$ pada jenis kemasan

maupun lama simpan keripik kentang.

Sehingga,dapat dikatakan dari kedua

interaksi antara jenis kemasan dan lama

penyimpanan ada pengaruh terhadap

kesukaan panelis pada warna keripik

kentang. Hasil uji lanjut Wilcoxon

menunjukkan ada beda antara pengaruh jenis kemasan dan lama simpan terhadap keripik

kentang.

Aroma

Aroma merupakan salah satu parameter dalam pengujian sifat sensori (organoleptik) dengan menggunakan indera penciuman. Aroma dapat diterima apabila bahan yang dihasilkan mempunyai aroma spesifik (Kusmawati, et al. 2000). 


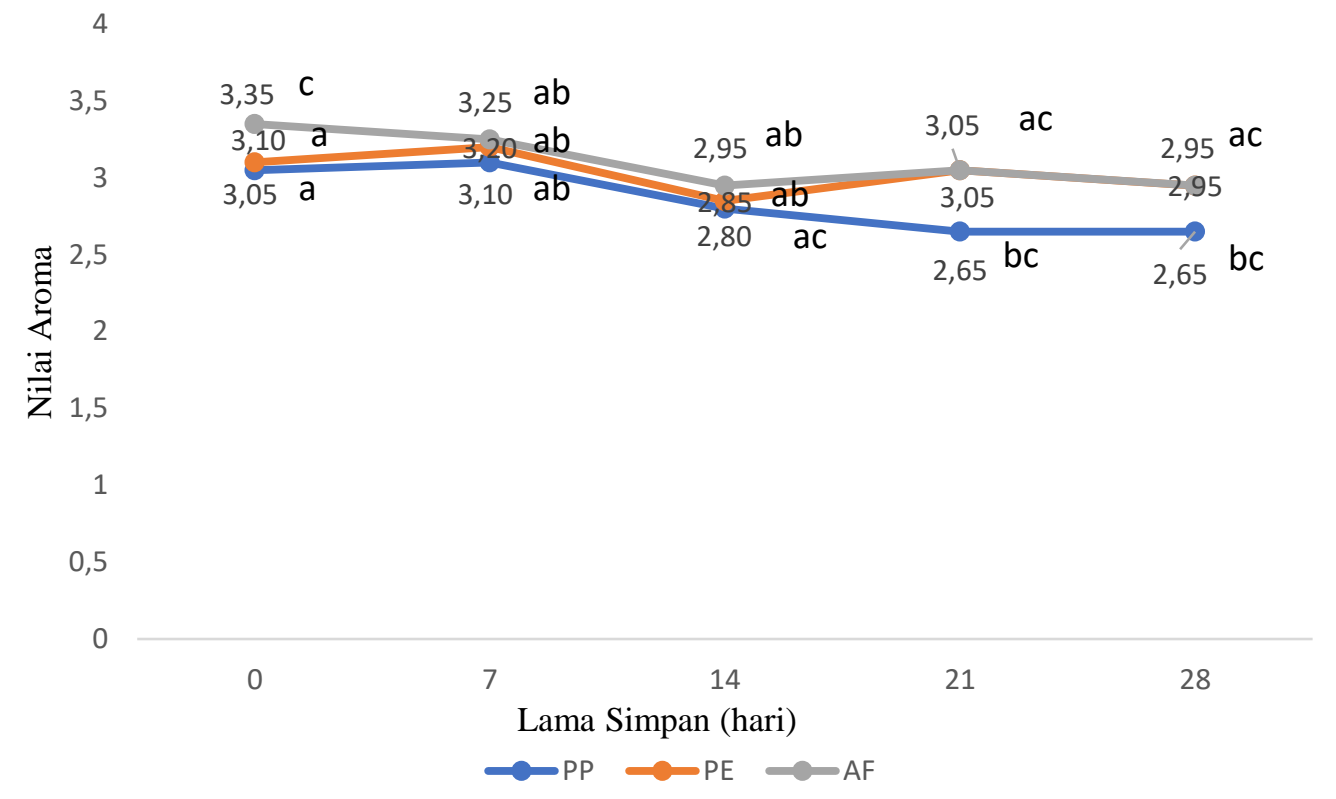

\section{Gambar 5. Rata-rata hasil analisis nilai aroma keripik kentang berdasarkan jenis kemasan dan lama penyimpanan}

Uji statistik Friedman didapatkan $\mathrm{P}=0,00<0,05$ antara jenis kemasan dengan lama simpan keripik kentang. Dapat disimpulkan bahwa ada pengaruh antara jenis kemasan dan lama simpan. Hasil uji lanjut Wilcoxon menunjukka ada beda antara jenis kemasan dan lama simpan keripik kentang terhadap perubahan warna yang terjadi seiring dengan lama simpan.

Nilai Rasa

Rasa merupakan faktor yang paling penting dalam mengambil keputusan terakhir untuk menerima atau menolak suatu makanan (Yulia et al. 2014). Walaupun warna, aroma, dan tekstur baik namun jika rasanya tidak enak maka konsumen akan menolak makanan tersebut. Hasil dari grafik rerata nilai rasa keripik kentang menunjukkan adanya penurunan tingkat kesukaan panelis pada nilai rasa yang dikemas dengan jenis plastik dan lama penyimpanan yang berbeda. Hal ini menunjukkan adanya perubahan rasa keripik kentang yang dikemas menggunakan jenis kemasan yang berbeda dengan lama simpan yang berbeda pula. Semakin lama penyimpanan maka nilai kesukaan rasa dari panelis semakin menurun. 


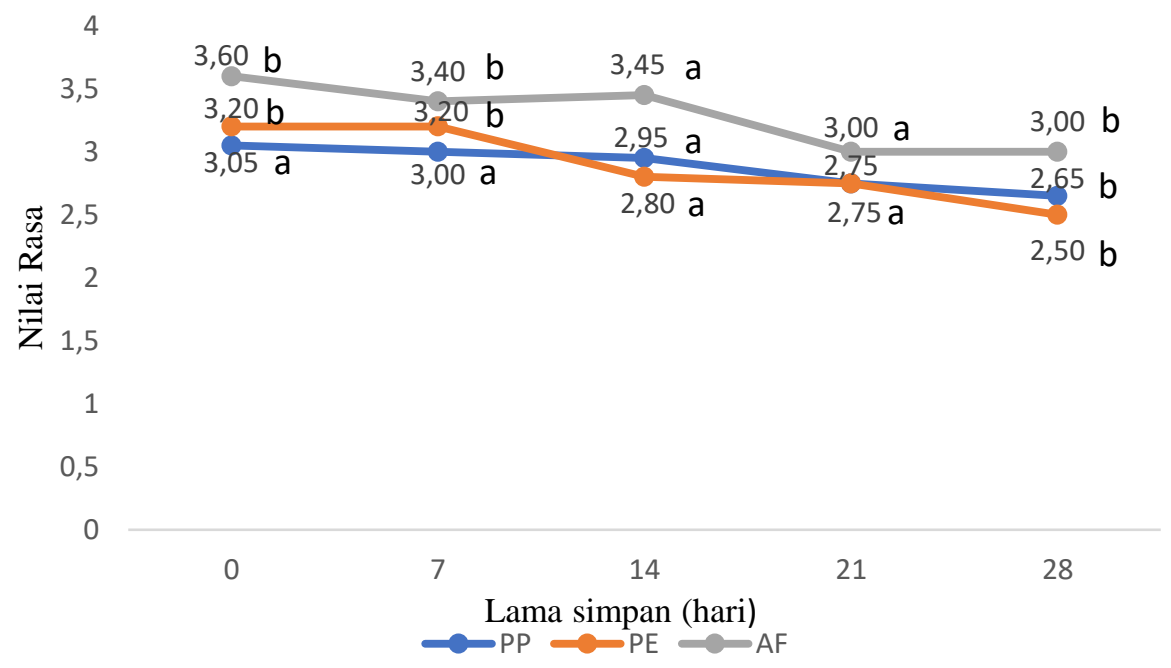

Gambar 6. Rata-rata hasil analisis nilai rasa keripik kentang berdasarkan jenis kemasan dan lama penyimpanan

Uji statistik Friedman didapatkan $\mathrm{P}=0,00<0,05$ pada semua jenis kemasan maupun pada lama penyimpanan terhadap rasa dari keripik kentang. Hal ini dapat disebabkan karena rasa dapat dipengaruhi oleh suhu,senyawa kimia yang menyusun bahan, dan tingkat kesukaan panelis pada produk hasil penggorengan keripik (Abdul hakim, 2015). Hasil uji lanjut Wilcoxon menunjukkan ada beda antara jenis kemasan dengan lama simpan keripik kentang. Hal ini dapat disimpulkan adanya perubahan dari nilai rasa yang dikemas dengan masingmasing kemasan terhadap masa simpan keripik kentang.

Nilai tekstur
Tekstur keripik kentang erat kaitannya dengan kerenyahan, tingkat kerenyahan dapat dipengaruhi oleh kadar air yang terdapat pada keripik kentang yang dihasilkan, begitu pula dengan kadar air bahan baku (kentang segar) akan berpengaruh pada kadar air keripik yang akan dihasilkan. Semakin rendah kadar air keripik yang dihasilkan, maka keripik akan semakin renyah (Wibowo, 2006). Tingkat kesukaan panelis terhadap nilai tekstur keripik kentang mengalami penurunan seiring dengan waktu lama simpan. Semakin lama masa simpan keripik kentang tingkat kesukaan panelis terhadap tekstur keripik kentang semakin menurun. Dapat dilihat pada Gambar 7. 


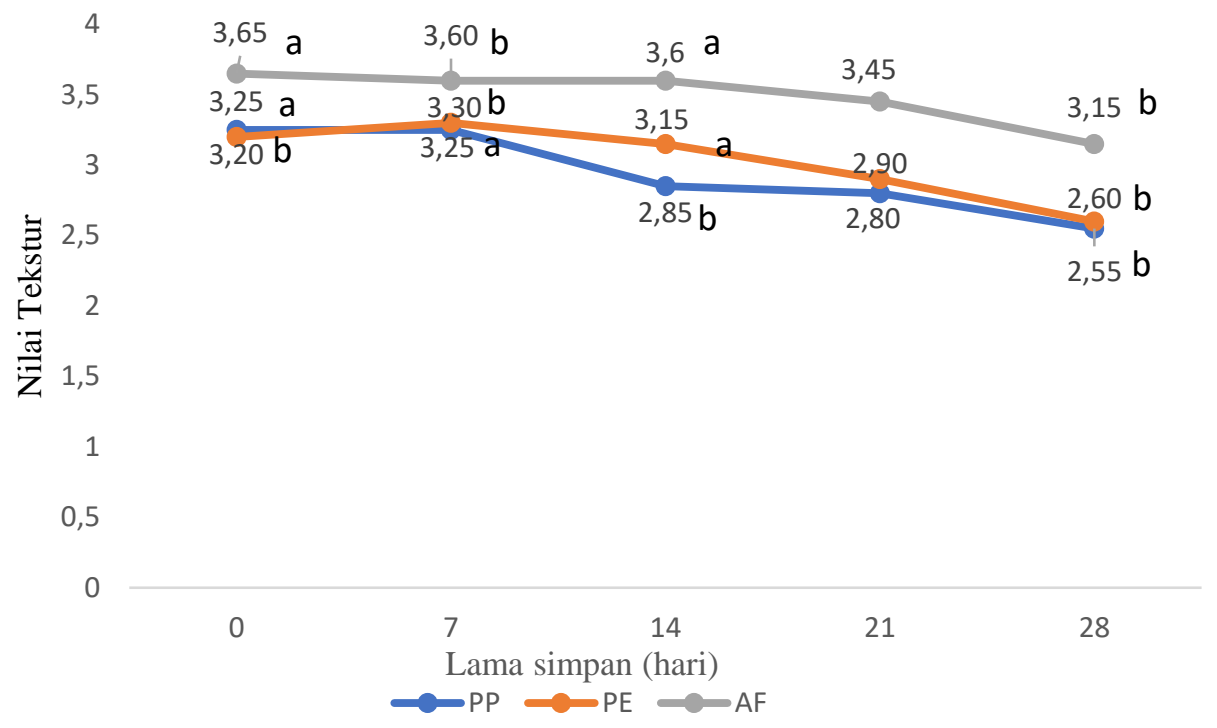

\section{Gambar 7. Rata-rata hasil analisis nilai tekstur keripik kentang berdasarkan jenis kemasan dan lama penyimpanan}

Uji statistik Friedman menunjukkan ada pengaruh dari interaksi antara jenis kemasan dan lama simpan dengan ditunjukkan $\mathrm{P}=0,00<0,05$. Hal ini dipengaruhi oleh beberapa faktor diantaranya kadar pati mempunyai peranan sebagai bagian utama bahan kering untuk meningkatkan kualitas khususnya tekstur renyah pada keripik dimana kadar pati yang rendah akan menghasilkan keripik kurang renyah (Wibowo, 2006). Hasil uji lanjut Wilcoxon menunjukkan ada beda antara jenis kemasan dan lama simpan. Dari data tersebut menunjukkan jenis kemasan dan lama simpan memberikan pengaruh terhadap nilai kesukaan panelis terhadap tekstur dari keripik kentang.

\section{KESIMPULAN}

Jenis kemasan dan lama penyimpanan memberikan pengaruh terhadap nilai FFA dan kadar air pada keripik kentang. Semakin lama penyimpanan maka semakin tinggi nilai FFA dan kadar air pada keripik kentang. Hasil statistik anova faktorial menunjukkan ada pengaruh jenis kemasan terhadap nilai FFA dan kadar air keripik kentang, hal ini menunjukkan ada beda pada jenis kemasan antara kemasan PP, PE, dan alumunium foil. Sedangkan, pada lama simpan tidak ada pengaruh terhadap nilai TBA keripik kentang. Hal ini 
menunjukkan masa simpan pada keripik kentang dengan akhir masa simpan 28 hari masih dalam kondisi baik untuk dikonsumsi karena belum terdapat perubahan yang signifikan pada keripik kentang.

Berdasarkan uji sensori pada nilai warna, aroma, rasa, dan tekstur menunjukkan ada pengaruh antara jenis kemasan dan lama penyimpanan pada keripik kentang. Ketiga jenis plastik yaitu Polypropilene, Polyethilene dan alumunium foil dengan ketebalan $0,55 \mathrm{~mm}$ baik digunakan untuk mengemas keripik kentang.

\section{DAFTAR PUSTAKA}

Adiyoga, W., A. Asgar., dan R. Suherman. 1999. Perilaku Konsumen Dalam Membeli Produk Keripik Kentang. Jurnal Hortikultura 9(3): 266-274.

Apriyantono, A, D., Ferdiaz, N.L. Puspitasari, Sudarnawati dan Budiyanto S. 1989. Petunjuk Laboratorium : Analisis Pangan. Institut Pertanian Bogor Press, Bogor.

Dewi MM, Bintoro N, dan Rahardjo B. 2012. Kinetika perubahan ketengikan (Rancidity) kacang goreng selama proses penyimpanan. J. Agritech, Vol. 32, No. 1.

Hani A.M. 2012. Pengeringan lapisan tipis kentang (Solanumtuberosum.L.) Varietas Granola. (Skripsi). Universitas Hasanuddin, Makasar.
Hutasoit H. 2009. Penentuan Umur Simpan Fish Snack (Produk Ekstrusi) menggunakan metode akselerasi dengan pendekatan kadar air kritis dan metode konveniona. (Skripsi).Institut Pertanian Bogor, Bogor.

Kusumawati, Aditya. 2013. Kualitas Es Krim Gembili (Dioscorea esculaenta Lour) Dengan Penambahan Daun Bayam Merah (Alternanthera amoena Voss). Skripsi. Surakarta : Universitas Muhammadiyah Surakarta.

Mudjisihono R., D Hindiarto., Z dan Noor. 2001. Pengaruh kemasan plastik terhadap mutu sawut kering selama penyimpanan. Jurnal Penelitian Pertanian . 20 (1): 55-65.

Nurhasnawati H. Supriningrum R. Caesariana. 2015. Penetapan kadar asam lemak bebas dan bilangan peroksida pada minyak goreng yang digunakan pedagang gorenga di Jl.A.W.Sjahranie Samarinda. J.Ilmiah, 1(1), 25-30. Akademi Farmasi Samarinda.

Sammet, K., R. Duehlmeire, H. P. Sallmann, C.von Canstein, T.von Mueffling and B.Nowak. 2006. Assesment of the antioxidative potential of dietary supplementation with a tocopherol in low nitrite salami type sausages. Meat Sci. 72:270-279

Wibowo. 2006. Peningkatan Kualitas Keripik Kentang Varietas Granola dengan Pengolahan Sederhana. J. Akta Agronesia. 9(2): 102-109.

Wijayanti R, Budiatra IW, dan Hasbulloh R. 2011. Kajian Rekayasa Proses Pengorengan Hampa dan Kelayakan Usaha Produksi Keripik Pisang. J.Food sci., 25(2):133-140.

Winarno, F.G. 2008. Kimia Pangan dan Gizi: Edisi Terbaru. Jakarta. Gramedia Pustaka Utama. 